\title{
DIE ROL VAN DIE ONDERWYS IN DIE HANDHAWING EN UITBOUING VAN ONS VOLKSKULTUUR
}

Op die oog af lyk dit 'n baie maklike onderwerp, maar hoe meer 'n mens daaroor nadink hoe ingewikkelder en omvangryker word die implikasies wat verband hou. Dit is veral so omdat dit hier voor alles gaan om eerste fundamentele uitgangspunte, dit wil sê, om lewens- en wêreldbeskouing. Dit geld van albei komponente - van onderwys sowel as van kultuur.

Ek kan dus ook nie daaraan dink (in die tyd tot my beskikking) om iets meer te doen, as om net enkele beskouinge oor die onderwerp te gee nie. Gelukkig kan ek hier ook gebruik maak van 'n onderskeiding deur prof. C. K. Oberholzer - 'n onderskeiding wat my goed pas. Nadat hy 'n hele reeks verskillende beskouingsrigtinge oor die Opvoedkunde bespreek het, verklaar hy: „Dit is duidelik dat die rigtinge wat onderskei en beskrywe is van 'n geweldige uitcenlopende aard is. Hulle weerkaats die onomstootlike feit, naamlik dat soos daar oor werklikheid, mens en lewe gedink word, so ook oor sinvolle mensehandeling as opvoeding... Dit was 'n suiwer beskrywende weergawe van hoe daar gedink en geoordeel word, sonder dat pro-hierdie of contradaardie gekies is. Die pedagogieker het nie nodig om te kies nie. Sy taak is om te weet watter beskouinge daar gehuldig word en wat die inhoudelikhede daarvan is. Die pedagogos of die man van die praktyk, moet kies. Gelukkig het hy reeds gekies, dikwels voordat hy met meerdere beskouingsrigtinge kennis gemaak het". Tot sover prof. Oberholzer. Ek sal my sover moontlik dan weghou van die taak van die pedagogieker en slegs probeer om uit die meer praktiese kant (hopelik darem met oorweging van sommige van die belangrikste beskouingsrigtings) so saaklik moontlik 'n paar standpunte in te neem.

Voordat ek dan 'n poging aanwend om aan te toon dat onderwys 'n rol speel in die handhawing en uitbouing van kultuur (volkskultuur) en kortliks ook hoe dit gedoen word, is dit nodig om eers iets te sê oor die twee genoemde komponente onderwys en kultuur.

Daar is werklik 'n veelheid van beskouinge oor opvoed- 
kunde en gevolglik ook oor opvoeding en onderwys en die doeleindes wat daarmee bereik moet word. Ek wil my voorlopig bepaal by die beskouing wat na my mening ook onderwys insluit en wat prof. Chris Coetzee soos volg gestel het:

„Opvoeding is ' $n$ opsetlike, bewuste, planmatige, doelbewuste en doelnastrewende werksaamheid, handeling of daad wat die vorming van die onvolwasse mens as mens op die oog het om hom daardeur uit 'n toestand van kinderlikheid oor en op te lei na 'n toestand van volwassenheid."

Maar die ware opvoeding van die mens, in sy volle omvang gesien, mag (aldus prof. Coetzee) ,nie bestaan net in die biologiese en sosiale aanpassing, die groei en ontwikkeling van die liggaam en die gees, die verskaffing en verwerwing van kennis, die vorming en ontwikkeling van die verstand tot waarheid, van die wil tot die goeie en van die smaak tot die skone nie. Dit moet die hele mens self tot sy voorwerp van behandeling hê; dit moet agter lewe en gemeenskap, agter liggaam en gees, agter kennis en verstand, agter wil en smaak, deurdring en die persoonlikheid self probeer vorm tot 'n mens van God wat volkome kan wees, vir elke goeie werk volkome toegerus".

'n Opvatting soos dié lei noodwendig tot 'n ooreenstemmende, uiteindelike opvoedingsdoelstelling waarin alles wat gestel is oor die onderwys moet bereik word op elke lewensterrein soos die biologiese, die fisiologiese, die psigologiese, sosiologiese, politiese, logiese, estetiese, etiese, filosofiese en die religieuse.

Oor die begrip kultuur bestaan daar net so 'n veelheid van beskouinge. Ek bepaal my in hierdie geval by die volgende siening van prof. J. E. Pieterse: „Kultuur is die totaliteit van die handelinge wat voortspruit uit en gestaltegewend is van die mens se bewuste, tradisionele en betekenisvolle materiële asook geestelike aktiwiteite en opvattings, soos dit in 'n bepaalde volksgemeenskap gerig word volgens die waarderingsbeeld van die mens en gemeenskap wat daarin gehandhaaf word, en aldus vorm kultuur 'n ingeweefde, onafskeibare deel van die mens se verhouding met en sy response op die openbaring van Gods gees en inspirasie. As sodanig is kultuur die gemeenskaplike besit van 'n volk en die uitinge van ' $n$ besondere nasieskap soos dit die menslike bestaan belewe en verwerk word ooreenkomstig bepaalde lewenswaar- 
des; en sodoende vorm kultuur die innerlike en uiterlike lewensgestalte van 'n volk'.

Uit die omskrywing van die begrip onderwys (opvoeding) en die begrip kultuur, kan na my mening die volgende afleidinge en toepassinge gemaak word: (En ek hoop dat hieruit duidelik genoeg sal blyk nie net dat onderwys kultuurvormend is nie, maar ook hoe dit geskied).

Eerstens dan: Kultuur sluit alles in wat die mens aan sowel geestesgoedere as stoflike besit verwerf het - en die onderwys/opvoeding vorm en ontwikkel sy verstand en gees sodat hy in staat gestel word om die stoflike besit te verwerf.

Tweedens: Kultuur is die gemeenskaplike besit van al die lede van 'n bepaalde volksgemeenskap - alhoewel dit nie in dieselfde mate by elkeen aangetref sal word nie - en die onderwys/opvoeding is juis die middel waardeur vorming en ontwikkeling van die jeug/mens op alle vlakke en in alle verbande - ook landswyd - dit wil sê, op volkswye grondslag, bewerkstellig word.

Derdens: Die mens, die kultuurmens, is 'n waarde wese. Hy besit ' $n$ waardebegrip of "waarderingsbeeld" van die menslike lewe, van menslike behoeftes, van sy plek, aandeel en bestemming in die Heelal - anders kan hy nie as kultuurmens bestaan, ontwikkel en voortbestaan nie. Deur die onderwys word hy gelei tot een van die hoogste vereistes, naamlik tot kennis van die waarheid - maar hy is ook sedelike wese. Hy moet dus ook kom tot kennis van die goeie. Die sedelike- en die wilsopvoeding, die estetiese, die filosofiese en die religieuse opvoeding het elk te maak met die bybring van ' $n$ bepaalde waardebesef en waardegehoorsaamheid by die mens.

Vierdens: Die kultuur van 'n volk karakteriseer daardie volk en bring sy eie-aard tot vergestalting. Die Christelike onderwys wat daarom ook nasionale of volkse onderwys is, sal vorming en ontwikkeling bewerkstellig wat organies aansluit by die volkskarakter.

Ten vyfde: Kultuurskepping moet gesien word „,as iets wat deur God aan die mens opgedra is om as sy mede-arbeider sy skepping ryker en heerliker uit te bou - tot groter eer en verheerliking van Hom. Die kultuur staan dan ook nie primêr in die diens van die mens nie, maar in diens van God. Kultuur en kultuurskepping met al sy fasette - kuns, letter- 
kunde, toneel, argitektuur, en so meer - impliseer derhalwe fundamenteel kultuur ter wille van en in diens van God. Kultuur bly dus 'n ingeweefde, onafskeibare, maar ook onverbiddelike deel van die verhouding van die mens met sy God. Met ander woorde, godsdiens en geloof in God en kultuur kan nie afsonderlik van mekaar bly bestaan of fungeer nie. Die persoon wat kultuur of kultuurskeppinge anders wil klassifiseer, bloot as net 'n skepping van die mens, en as sodanig nie 'n Hoër Gesag daarin wil erken en verheerlik nie, hou kultuur op 'n horisontale vlak en verkondig daarmee 'n humanisme wat die mens as maatstaf van alle dinge stel" - aldus prof. Pieterse. En van die doel van opvoeding en onderwys sê prof. Coetzee: „Die vrees van die Here is die hoogste doel van ons lewe en opvoeding. En dit vind ons alleen by die mens van God wat volkome toegerus is vir elke werk. Die einddoel van die opvoeding omvat weer al die nabysynde en verwyderde doelstellinge. Die aanpassing van die mens aan sy omgewing, die oefening van sy liggaam, die ontwikkeling van sy gees, die vervulling van sy lewenstaak, die gehoorsaamheid aan die owerheid, die vorming en ontwikkeling van sy verstand, sy deugdelike lewe, sy estetiese vorming en ontwikkeling, sy gevormde en gevestigde lewens- en wêreldbeskouing, dien alles per slot van rekening weer net die hoofdoel van sy lewe: die vrees van die Here wat hom openbaar in die waaragtige godsvrug".

Uit hierdie paar afleidinge, toepassinge of vergelykings blyk dit na my mening duidelik genoeg dat die onderwys 'n baie groot rol speel in verband met kultuurvorming by die mens en gevolglik by die volk. Die onderwys, wat self kultuurproduk is, word die medium, die middel of proses waardeur die onvolwassene sy volwassenheid verkry - die vermoë om kultuur te skep en kultuurmens te wees. Die mens wat opgevoed is, is dan ook kultuurmens. Hoe hoër die vlak van sy opvoeding is, hoe ontwikkelder, hoe ryker sal sy kultuur wees - en omgekeerd hoe primitiewer die opvoeding en onderwys van die mens, des te primitiewer ook sy kultuur. Hieruit blyk dan nie alleen dat onderwys 'n rol speel in kultuurvorming nie, maar ook hoe dit plaasvind.

Handelende oor die onderwys en die Westerse kultuur en die onderlinge vervlegtheid van die een met die ander het prof. C. K. Oberholzer dit so gestel: „Daar is 'n geweldige 
taak vir die rekening van opvoeding en onderwys in die oordrag en bestendiging van die Westerse kultuurwaardes. Oordrag en bestendiging is menslike aangeleenthede en dus menslik gebrekkig en beperk. In weerwil hiervan kan ons vorder en aan die Westerse leefwyse groeiende vergestalting gee mits ons bereid is om aan die kultuureise te voldoen. Ons kan aan hierdie eise voldoen op voorwaarde dat ons ons waardigheid en dié van ons kinders beoefen en beskerm, en dit beteken om óns verantwoordelikhede na te kom en hulle te help om hulle vryheid onder simpatieke gesagsleiding te verwerf ten einde die eise daarvan te erken en te beantwoord". Wat hier geld ten opsigte van die onderwys en die Westerse kultuur - geld myns insiens ook van die onderwys en volkskultuur.

Maar die onderwys speel nie alleen 'n rol met betrekking tot die handhawing van ons volkskultuur nie, dit het ook 'n beslissende rol in verband met die uitbouing daarvan. Opvoeding en onderwys, as kultuurproduk, word nie alleen 'n instrument vir elke nuwe generasie om die bestaande kultuur te verwerf nie, maar ook om in ooreenstemming met die eieaard van die jeug en van die bestaande kultuur, bouwerk te doen. Hierdie uitbouing geskied ook in ooreenstemming met die eie-aard van die onderwys en opvoeding self. Hiermee is dan ook gesê dat bepaalde kultuurhandhawing en uitbouing slegs kan geskied deur ' $n$ bepaalde soort opvoeding en onderwys.

Indien ons dus in Suid-Afrika dié soort opvoeding en onderwys wat vroeër gestel is met die daarby genoemde doelstellinge met welslae toepas, sal ons ons jeug vorm en lei tot 'n volwassenheid wat 'n bepaalde kultuur sal handhaaf en bou. Dit sal nie sommer enige kultuur wees nie - dit sal die kultuur van die Afrikaner wees - van die gelowige Christen - (Calvinistiese) Afrikaner.

Ek het vroeër daarop gewys dat daar 'n veelheid van opvattinge oor en doelstellinge vir die onderwys en opvoeding bestaan. Laat my nou baie saaklik 'n paar noem:

Die Idealiste se onderwys sal strewe na die selfverwesenliking van die mens as 'n redelik-sedelike, harmoniese en ewewigtige persoonlikheid; die Totalitariste na ware of doeltreffende Staatsburgerskap; die Utiliste na kennis en vaardigheid ter wille van selfbehoud; die Humaniste na aardse wys- 
heid en deug; die Naturaliste en Pragmatiste na aanpassing van die individu by sy omgewing.

As enigeen van hierdie beskouinge of praktyke met sy genoemde doelstelling in Suid-Afrika toegepas word, is dit begryplik dat 'n totaal andersoortige invloed op ons volkskultuur losgelaat sal word. Dit sal ongetwyfeld wesenlik verskil van die invloed van die onderwys en opvoeding wat ons aanvanklik beskryf het.

Indien ons dus glo dat ons 'n gelowige Christen - (Calvinistiese) volk is met 'n kultuur wat daarby pas, dan sal ons 'n Christelike (Calvinistiese) onderwys soos ek beskryf het, moet gebruik as ons die eie aard (die eie of bestaande kultuur) van die volk wil handhaaf en bou. As 'n ander onderwys gebruik word sal sy invloed mense lewer wat gereed en in staat is tot ' $n$ ander kultuur. Indien 'n vermenging van die soorte onderwys gebruik word, sal die mense wat daardeur gevorm en gelei is neutraal, verward en sonder koers of inspirasie wees - met dienooreenkomstige invloed op dic bestaande kultuur.

Indien die eie aard van ons Engelssprekende landgenote as volksgroep in wesenlike opsigte ernstig verskil van dié van die Afrikaanssprekendes en veral as hulle globaal gesien, lewe uit 'n radikaal verskillende lewens- en wêreldbeskouing, sal enige enkele soort onderwys (soos getipeer) en toegepas op albei genoemde bevolkingsgroepe nie in staat wees om die kultuur (eie aard) van elke afsonderlike groep te handhaaf en te bou nie. Die onderwys moet gesien word as kultuurproduk en wel van 'n besondere volk (volksgroep) en sal, indien dit sy doel met welslae moet dien, die kultuur (die eie-aard) van daardie volk of groep handhaaf en bou.

Die feit dat ons met betrekking tot die wesenlik belangrike karaktertrekke van ons onderwys in Wet 39 van 1967 kon inskrywe dat dit 'n Christelike en 'n nasionale karakter sal hê, en dit met instemming en ondersteuning van uns Engelssprekende volksgenote, stel my in staat om te hoop dat ons dieselfde onderwys (soos hier oorspronklik voorgestel) kan toepas op albei volksgroepe sonder wesenlike benadeling van die handhawing en uitbouing van die betrokke kultuur of eie aard. Of dit egter werklik in die sin sal slaag sal myns insiens in 'n hoë mate afhang van die wyse waarop ons inhoud sal gee aan die voorgenome beleidsbepaling in ver- 
band met die Christelike en die nasionale karakter van ons onderwys.

Dit is daarom van kardinale belang dat daar spoedig deur die Afrikaanssprekendes inhoud gegee word aan en ooreengekom word oor die begrip en bedoeling van Christelik en nasionaal en van Christelik-nasionaal - in die onderwys veral. Dié inhoudgewing sal só gestel moet word dat dit kan onderskryf word deur ons Afrikaanse kerke sowel as deur die Regering. En ek glo dat as ons dit eerlik, duidelik en opreg gedoen het, ons 'n goeie vooruitsig het dat dit ook (na wyse oorlegpleging met ons Engelssprekende volksgenote) deur hulle aanvaar sal word.

Indien dit wel gebeur sal ons 'n lewenskragtige onderwys kan ontwikkel wat 'n beslissende rol sal speel in die handhawing en uitbouing van 'n Christelik (Calvinistiese) Afrikaanse kultuur en 'n Christelik (Calvinistiese) Engelse kultuur. Indien dit nie gebeur nie, sal die invoeging van die Christelike en nasionale karakter van die onderwys in die Wet, niks meer vermag as wat vandag reeds praktyk is nie.

Omdat ek onderwysmens is glo ek dat ons sal slaag of as ek nie glo nie, dan hoop ek ten minste.

G. J. Jordaan.

Pretoria. 